\title{
Comportamiento ingestivo de vacas en una asociación grama nativa/Arachis pintoi en el trópico húmedo veracruzano
}

\section{Ingestive behavior of cows in a native grass/Arachis pintoi association in the humid tropic of Veracruz}

\author{
Epigmenio Castillo Gallegosa, Rodrigo Rascón Chincoyab, Diana García Gonzálezb, \\ Jesús Jarillo Rodrígueza, Andrés Aluja Schunemannc, Len 't Mannetjed
}

\begin{abstract}
RESUMEN
Se introdujo la leguminosa Arachis pintoi CI AT 17434 (AP) en una pastura de gramas nativas, para estudiar su efecto sobre la conducta de ingestión del animal al pastar, en la época lluviosa del trópico húmedo del estado de Veracruz. Los tratamientos fueron gramas nativas (PN, testigo) y AP asociado a gramas nativas (PNA). La rotación fue 1 día de pastoreo/ 20 días de recuperación con carga de 3.2 vacas F1 (Holstein $x$ Cebú)/ ha. Las diferencias se probaron a $P<0.05$, presentándose primero las medias \pm error estandar de PNA y luego de PN. Hubo diferencias entre tratamientos en cantidad de materia seca (MS) presente antes del pastoreo (4,225 \pm 212 vs 3,314 $\pm 212 \mathrm{~kg} / \mathrm{ha})$, así como en proteína cruda (15.1 \pm 0.45 vs $10.6 \pm 0.5 \%)$ y materia orgánica (MO) digestible (67.65 \pm 1.7 vs $64.1 \pm 2.4 \%)$ de la extrusa esofágica. El tiempo de pastoreo (367 \pm 11 vs $380 \pm 11 \mathrm{~min} / 24 \mathrm{~h}$ ) fue similar entre tratamientos y el de rumia diferente ( $291 \pm 8$ vs $379 \pm 8 \mathrm{~min} / 24$ h). No hubo diferencias en consumo de MO calculado por Cr-indigestibilidad in situ (2.09 \pm 0.11 vs $2.16 \pm 0.11 \mathrm{~kg} \mathrm{MO} / 100 \mathrm{~kg}$ PV), pero por comportamiento ingestivo, si las hubo (1.54 \pm 0.12 vs $2.02 \pm 0.12$ ). La producción diaria ( $\mathrm{kg} / \mathrm{vaca})$ de leche ordeñada (6.8 $\pm 0.4 \mathrm{vs} 6.1 \pm 0.4)$ y consumida por el becerro $(4.4 \pm 0.4 \mathrm{vs} 3.8 \pm 0.5)$ fueron similares, pero la producción total fue diferente $(9.0 \pm 0.6 \mathrm{vs} 7.2 \pm 0.6 \mathrm{~kg} / \mathrm{animal} /$ día).
\end{abstract}

PALABRAS CLAVE: Arachis pintoi, Comportamiento ingestivo, Extrusa esofágica, Calidad nutricia.

\begin{abstract}
A study was conducted in the humid tropics of the state of Veracruz during the rainy season, in order to determine the effect of introducing the legume Arachis pintoi CI AT 17434 (AP) into a native pasture, upon the grazing ingestive behavior of cows. Treatments were the native pasture (PN, control) and PN associated with AP (PNA). A 1 d grazing/ $20 \mathrm{~d}$ recovery rotation and a stocking rate of 3.2 F1 (Holstein $\times$ Cebú) cows/ ha were used. Significance was set at $P<0.05$. Means \pm standard error are presented for PNA first and then for PN. There were differences in standing dry matter ( $\mathrm{kg} / \mathrm{ha})$ before grazing $(4,225 \pm 212 \mathrm{vs} 3,314 \pm 212 \mathrm{~kg} / \mathrm{ha})$, and crude protein (15.1 $\pm 0.4 \mathrm{vs} 10.6 \pm 0.5)$ and digestible organic matter (OM) $(67.6 \pm 1.7$ vs $64.1 \pm 2.0 \%)$ of oesophageal extrusa. Grazing time (min/ $24 \mathrm{~h})$ was similar between treatments $(367 \pm 11$ vs $380 \pm 11)$, but ruminating time was not $(291 \pm 8$ vs $379 \pm 8)$. OM intake ( $\mathrm{kg} \mathrm{OM} / 100 \mathrm{~kg} \mathrm{LW})$ calculated by $\mathrm{Cr}$-in situ digestibility was similar between treatments (2.09 \pm 0.11 vs 2.16 \pm 0.11 ), while intakes calculated by ingestive behavior were different (1.54 \pm 0.12 vs $2.02 \pm 0.12$ ). Saleable milk yield and milk intake by calf $(\mathrm{kg} /$ animal/ $\mathrm{d})$ were similar between treatments: $6.8 \pm 0.4$ vs $6.1 \pm 0.4$; and $4.4 \pm 0.4$ vs $3.8 \pm 0.5$, but total milk yield was different: $9.0 \pm 0.6$ vs $7.2 \pm 0.6$.
\end{abstract}

KEY WORDS: Arachis pintoi, Ingestive behavior, Oesophageal extrusa, Nutritive quality.

Recibido el 28 de agosto de 2010. Aceptado el 18 de enero de 2011.

a Centro de Enseñanza, Investigación y Extensión en Ganadería Tropical, Facultad de Medicina Veterinaria y Zootecnia, Universidad Nacional Autónoma de México. AP 136, Martínez de la Torre, Veracruz, 93600 México. Tel \& fax: (232) 3243941. pime11302002@yahoo.com.mx. Correspondencia al primer autor.

b Escuela de Ingeniería Agronómica Zootecnista, Facultad de Ingeniería Agrohidráulica, Benemérita Universidad Autónoma de Puebla. México.

c Coordinación de Investigación y Relaciones Interinstitucionales, Universidad Autónoma de Yucatán. México.

d Profesor Emérito $(\dagger)$, Universidad de Wageningen, Países Bajos. 
El objetivo de la administración de pasturas es manipular la cantidad de forraje ofrecido y su composición botánica, así como la calidad, para maximizar el desempeño productivo animal. Al pastar, el rumiante emplea la vista, el gusto, el olfato y el tacto para seleccionar el bocado de pastura que va a ingerir(1). Entonces, los cambios en las características de la pastura inducirían cambios en el patrón normal de forrajeo del animal y afectarían la cantidad y calidad del alimento ingerido. Por consiguiente, se vería también afectada la conducta de alimentación en pastoreo del animal al pastar, entendida ésta como las actividades y el tiempo que cada actividad toma al animal para adquirir el alimento que lo nutre. Tales actividades son: apacentamiento (pastoreo), rumia, y otras distintas, como beber agua, caminar y descansar, ya sea echado o de pie. Por medio de observaciones directas es posible cuantificar los tiempos que toma al animal cada actividad. Por tal motivo, es recomendable describir también la conducta de alimentación del animal y cómo la afecta el manejo de la pastura(2).

Además, la cantidad y calidad de la materia seca (MS) ingerida son mediciones necesarias para explicar diferencias en producción animal de pasturas cuya administración es diferente(3). El consumo de MS, así como su calidad y la relación con la conducta de alimentación del rumiante, ha sido estudiado en pasturas asociadas de gramíneas introducidas y $A$. pintoi con razas productoras de carne principalmente $(4,5,6)$. Sin embargo, estos estudios son escasos en asociaciones de gramas nativas con $A$. pintoi y con otro tipo de animales, y que se hacen necesarios debido a que las gramas nativas son una vegetación inducida de gran importancia en la ganadería de doble propósito del trópico mexicano, ya que dependiendo de la región que se trate, forman del 25 hasta el $70 \%$ de las áreas de pastoreo (7). Las gramas nativas producen menos biomasa y ésta es de menor calidad, que las gramíneas introducidas. Además, su crecimiento es marcadamente estacional, pero su establecimiento es sencillo y de bajo costo, y una vez establecidas son persistentes(7).
The goal of pasture management is to control the amount of forage offered and their botanical composition in order to maximize animal production performance, as well as the quality. During grazing, ruminants use sight, taste, smell and touch to select the bite pasture patch that they will eat(1). However, changes in the characteristics of the pasture induce changes in the normal pattern of animal foraging and affect the quality and quantity of food ingested. Therefore, feeding behavior of grazing animals, understood as the activities and the time each activity takes the animal to acquire its food that nourishes them, is affected in the pasture. Such activities include grazing, rumination, as well as others such as drinking water, walking and resting, either lying down or standing. Through direct observation it is possible to quantify the time the animal takes for each activity. Hence, it is possible to also describe the feeding behavior of the animal and how it is affected by pasture management(2).

In addition, the quantity and quality of dry matter (DM) ingested are measurements necessary to explain differences in animal production with different pasture management techniques(3). DM intake and its relation to quality and feeding behavior of ruminants has been studied in pastures with introduced grasses and $A$. pintoi, but mainly with beef producing cattle breeds $(4,5,6)$. However, these studies are scarce with respect to associations of native grasses and $A$. pintoi and other type of cattle. Therefore this type of studies are necessary because native-grass based pastures are of great importance in the dual purpose cattle systems of the Mexican tropics because, since depending on the region in question, they make-up 25 to $70 \%$ of the grazing area(7). The native grasses produce less biomass and have lower quality than the introduced grasses. In addition, growth is markedly seasonal, but its establishment is simple and inexpensive, and once established it is persistent(7).

The aim of this study was to determine the effect of introducing Arachis pintoi CIAT 17434 
El objetivo del presente estudio fue determinar el efecto de introducir Arachis pintoi CIAT 17434 en una pastura de gramas nativas, sobre la calidad del forraje ingerido y la conducta de alimentación en pastoreo de vacas de doble propósito ( $F 1$, Holstein x Zebu) en el trópico húmedo del estado de Veracruz.

El estudio se llevó a cabo en la época de lluvias, de junio 25 a agosto 14 del 2000, en el Centro de Enseñanza, Investigación y Extensión en Ganadería Tropical (CEIEGT) de la Facultad de Medicina Veterinaria y Zootecnia de la UNAM, el cual está situado a unos $40 \mathrm{~km}$ al oeste de la línea costera del Golfo de México $\left(20^{\circ} 02^{\prime} \mathrm{N}\right.$, $97^{\circ}$ 06' W, $112 \mathrm{msnm}$ ). Hay tres épocas climáticas: lluviosa (julio-octubre), con altas precipitaciones y temperaturas; invierno 0 "nortes" (noviembre-febrero), con temperaturas bajas y menor lluvia que la anterior; y seca (marzo-junio) con altas temperaturas y escasas lluvias. Los nortes y la sequía son periodos de bajo crecimiento del pasto debido a bajas temperaturas y alta demanda evaporativa, respectivamente. Los suelos son ultisoles ácidos (pH 5.4), con bajos contenidos de fósforo (12 ppm; Bray II) y nitrógeno $(0.0018 \%)$ y contenidos medios de materia orgánica $(2.4 \%)$; su textura es arcillo limosa. La delgada capa arable $(0$ a $25 \mathrm{~cm}$ ) descansa directamente sobre arenisca compactada, llamada localmente tepetate, característica que extrema los efectos negativos de la sequía sobre el crecimiento de la pastura(7).

Las pasturas de gramas nativas (PN) empleadas en el presente estudio, se originaron de pasturas de especies introducidas que se establecieron al inicio de los $80 \mathrm{~s}$, y luego fueron paulatinamente invadidas, principalmente por gramíneas nativas y algunas leguminosas, que se volvieron dominantes a principios de los 90s. Entre las gramíneas nativas presentes en cantidades importantes están los pastos trencilla (Paspalum notatum y $P$. plicatulum), carpeta (Axonopus affinis y $A$. compressus), cola de zorra (Setaria sp), Bermuda (Cynodon dactylon) y malezas de importancia como los pastos amargo (Paspalum in a pasture of native grasses on the quality of ingested forage and grazing feeding behavior of dual-purpose cows (F1 Holstein $x$ Zebu) in the humid tropics in the state of Veracruz.

The study was conducted in the rainy season, from J une 25 to August 14, 2000, at the Center for Teaching, Research and Extension in Tropical Livestock (CEIEGT), Faculty of Veterinary Medicine of UNAM, which it is located about 40 $\mathrm{km}$ west of the coastline of the Gulf of Mexico $\left(20^{\circ} 02^{\prime} \mathrm{N}, 97^{\circ} 06^{\prime} \mathrm{W}, 112 \mathrm{~m}\right.$ asl). There are three climatic seasons: rainy (July to October), with high rainfall and temperatures; winter or "North-wind" (November-February), with low temperatures and less rain than the former; and dry (March to J une) with high temperatures and low rainfall. The North-wind and dry periods are times of low pasture growth due to low temperatures and high evaporative demand, respectively. Soils are acid ( $\mathrm{pH} \mathrm{5.4)}$ ultisols with low phosphorus content (1-2 ppm; Bray II) and nitrogen $(0.0018 \%)$ and organic matter content $(2.4 \%)$; its texture is salty clay. The thin topsoil (0 to $25 \mathrm{~cm}$ ) rests directly on compacted sandstone; this feature is locally called "tepetate", with characteristics that increase the extreme negative effects of pasture growth during the dry season(7).

The pastures of native grasses (PN) used in this study originated from pastures of introduced species that were established at the beginning of the 1980s, and then were gradually invaded mainly by native grasses and some legumes, which became dominant in the early 1990s. Among the native grasses that are present in significant quantities are braid grasses (Paspalum notatum and P. plicatulum), folder (Axonopus affinis and A. compressus), foxtailgrass (Setaria sp), Bermudagrass (Cynodon dactylon) and weeds of importance such as sourgrass (Paspalum virgatum) and savannahgrass (Sporobolus poiretii). Native legumes like "pega-pega" (Desmodium spp) and the weed "pinahuistle" (Mimosa pigra) are also present in the pastures, but to a much lesser extent than grasses. These rotational grazing 
virgatum) y sabana (Sporobolus poiretii). Aunque en menor contenido en la composición botánica, están las leguminosas pega-pega (Desmodium spp) y otras consideradas como malezas, como el pinahuistle (Mimosa pigra).

Estas pasturas recibieron pastoreo rotacional (2 a 3 días de pastoreo, 50 a 70 días de recuperación) con una carga animal promedio de $1.25 \mathrm{UA} / \mathrm{ha}$ entre diciembre de 1993 y octubre de 1994, periodo en que su composición botánica fue: $39 \%$ de gramíneas introducidas (GI), $48 \%$ de gramíneas nativas (GN), $3 \%$ de arvenses de hoja ancha (MA), $6 \%$ de arvenses de hoja angosta (MN) y $5 \%$ de leguminosas nativas (LN).

Hubo dos tratamientos: la pastura de gramas nativas (PN) como testigo y la pastura experimental (PNA), en la cual se introdujo Arachis pintoi (CIAT 17434); cada una ocupó 2.5 ha. La primera se implementó en 1996 a partir de gramas nativas ya establecidas. El $A$. pintoi se plantó vegetativamente en las gramas nativas empleando una distancia entre surcos de $1.0 \mathrm{~m}$ y entre plantas de $0.5 \mathrm{~m}$, entre agosto y noviembre de 1996, y fue pastada por vez primera en mayo de 1997. Cada pastura se dividió en 21 potreros con el fin de llevar a cabo el pastoreo rotacional de 1 día de pastoreo por 20 días de descanso. La carga animal aplicada en el periodo experimental fue de 3.2 vacas/ha, que de acuerdo a los pesos de las vacas durante el experimento fueron equivalentes a 3.2 y a 3.6 unidades animal (UA $=450 \mathrm{~kg}$ PV) por hectárea para PN y PNA, respectivamente.

Se utilizaron ocho vacas intactas (VIN, sin fístula esofágica), de la cruza F1 (Holstein x Cebú) por tratamiento, cuyo peso promedio \pm desviación estándar fueron $450 \pm 64 \mathrm{~kg}$ para PN y de $505 \pm 61 \mathrm{~kg}$ para PNA, las cuales se manejaron en un sistema de doble propósito, con ordeña una vez al día por la mañana, tiempo en el cual se suplementaron con aproximadamente $1.2 \mathrm{~kg}$ de melaza/vaca/día (» $1 \mathrm{~kg} \mathrm{MS/vaca/}$ día). En sus primeros cuatro meses de lactancia pastures received 2 to $3 \mathrm{~d}$ of grazing with 50 to $70 \mathrm{~d}$ of recovery with an average stocking rate of $1.25 \mathrm{AU} /$ ha between December 1993 and October 1994, during which its botanical composition was: $39 \%$ of introduced grasses (IG), $48 \%$ of native grasses (NG), $3 \%$ broadleaf weeds (BW); $6 \%$ narrow leaf weeds $(\mathrm{NW})$; and $5 \%$ native legumes (NL).

There were two types of pasture: the native grass pasture (NP) as a control and experimental associated pasture or grass blend (NPA), in which Arachis pintoi (CIAT 17434) was introduced; each occupied 2.5 ha. The first was implemented in 1996 from established native grasses. A. pintoi was vegetatively planted in native grasses using a row spacing of $1.0 \mathrm{~m}$ and $0.5 \mathrm{~m}$ between plants, between August and November 1996, and was grazed for the first time in May 1997. Each pasture was divided into 21 paddocks in order to carry out the rotational pasture grazing of $1-d$ and $20-d$ of recovery. Stocking rate applied in the experimental period was 3.2 cows/ha, according to the weights of the cows during the experiment and were equivalent to 3.2 and 3.6 Animal Units ( $A U=450 \mathrm{~kg} \mathrm{BW}$ ) per hectare for NP and NPA, respectively.

Eight intact cows (VIN, without esophageal fistula), of the F1 (Holstein x Zebu) cross were used per pasture treatment; the average weight \pm standard deviation was $450 \pm 64 \mathrm{~kg}$ for the control pasture (NP) and $505 \pm 61 \mathrm{~kg}$ for the experimental grass blend pasture (NPA), where there were managed in a dual purpose system being milked once daily in the morning, at which time they were supplemented with approximately $1.2 \mathrm{~kg}$ of molasses/cow $/ \mathrm{d}$ (» $1 \mathrm{~kg} \mathrm{MS} / \mathrm{cow} / \mathrm{d}$ ). In the first 4 mo of lactation they suckled their calves at the same time for 30 min after milking $(0800 \mathrm{~h})$ and in the afternoon (1400 h). Also, two esophageal fistulated cows (EFC) of the $3 / 4$ Holstein- $1 / 4$ Zebu cross were used, which grazed on pastures similar to the experimental ones and weighed on average $576 \pm 68 \mathrm{~kg}$. There were also three bulls fitted with a permanent 
amamantaron sus becerros por 30 min después del ordeño $(0800 \mathrm{~h})$ y por el mismo tiempo en la tarde (1400 h). Se usaron además dos vacas fistuladas al esófago (VFE), de la cruza $3 / 4$ Holstein - $1 / 4$ cebú, que pastaron potreros similares a los experimentales y pesaron en promedio $576 \pm 68 \mathrm{~kg}$. Adicionalmente se contó con tres toros con fístula ruminal provistos de cánulas permanentes con tapón removible, cuyo peso promedio fue de $550 \pm 65 \mathrm{~kg}$.

Las mediciones en las pasturas y animales se llevaron a cabo del 25 de junio al 14 de agosto del 2000. Para evitar causar estrés a las vacas fistuladas al esófago a causa de muestreos frecuentes, las mediciones de comportamiento ingestivo se realizaron primero en el tratamiento PNA, durante los 21 días seguidos del ciclo de pastoreo (periodo 1, 25 de junio a 15 de julio) y luego, en el tratamiento $\mathrm{PN}$ en el ciclo siguiente (periodo 2, 25 de julio al 14 de agosto).

Se muestrearon los 21 potreros de cada tratamiento, estimando la MS presente (MSP, $\mathrm{kg} / \mathrm{ha}$ ) antes del pastoreo con el método del rendimiento comparativo(8). En los cuadrantes de referencia, el forraje se cortó a ras de suelo y luego se secó en estufa de aire forzado por $48 \mathrm{~h}$ a $62{ }^{\circ} \mathrm{C}$ para estimar el contenido de MS. La composición botánica ( $\mathrm{CB}, \%)$ se estimó con el método de rangos de peso seco(9). La MSP y la CB se calificaron visualmente en 100 cuadrantes por potrero. Se consideraron los componentes botánicos: A. pintoi (AP), gramíneas nativas (GN) e introducidas $(G I)$, arvenses de hoja ancha (MA) y de hoja angosta (MN) y leguminosas nativas (LN); asimismo, en la $\mathrm{CB}$, los pastos amargo (Paspalum virgatum) y sabana (Sporobolus poiretii) se consideraron como especies individuales y no dentro del grupo de especies de gramíneas nativas, ya que son malezas importantes en las pasturas experimentales y a nivel regional, además que son poco consumidas por el ganado.

Las principales especies en los distintos grupos botánicos fueron: GN - pasto bahía (Paspalum rumen fistula and cannula with a removable cap, with an average weight of $550 \pm 65 \mathrm{~kg}$.

Measurements in pastures and animals were carried out from June 25 to August 14, 2000. To avoid stress to the esophageal fistulated cows because of frequent sampling, measurements of feeding behavior were first made with the NPA experimental association, for $21 \mathrm{~d}$ followed by a grazing cycle (period 1, June 25- July15) and then in the next cycle with the NP (period 2, July 25 to August 14).

A total of 21 paddocks of each treatment were sampled, estimating the amount of standing DM present (SDM, $\mathrm{kg} / \mathrm{ha}$ ) before grazing, using the comparative yield method(8). In five reference quadrants, forage was cut at ground level and then dried in a forced air oven for $48 \mathrm{~h}$ at $62{ }^{\circ} \mathrm{C}$ to estimate DM content. Botanical composition (BC, \%) was estimated with the dry-weight-rank method(9). The SDM and BC was visually graded on 100 quadrants per plot. The botanical components considered were: $A$. pintoi (AP), native grasses (NG) and introduced (IG) broadleaf weeds (BW) and narrow leaf weeds (NW) and native legumes (NL). Also in the $\mathrm{CB}$, the bitter grasses (Paspalum virgatum) and Savannahgrass (Sporobolus poiretii) were considered as individual species, not within the group of NG or NL, as they are important in the experimental pastures and at the regional level, although only a small amount are consumed by livestock.

The main species in the different botanical groups were: NG - bahiagrass (Paspalum notatum), $P$. dilatatum, $P$. plicatulum, $P$. conjugatum, carpet grass (Axonopus affinis and A. compressus), Bermuda grass (Cynodon dactylon) and Setaria spp.; IG - African star grass (Cynodon nlemfuensis) and tanner grass (Brachiaria arrecta); NW - Cyperus spp, BW "little brush" (Sida acuta) and legumes like Mimosa pudica and M. pigra; and NL- species of genus Desmodium, Centrosema and Rhynchosia. 
notatum), $P$. dilatatum, $P$. plicatulum, $P$. conjugatum, pastos alfombra (Axonopus affinis y $A$. compressus), pasto Bermuda (Cynodon dactylon) y Setaria spp.; GI - pasto estrella de África (Cynodon nlemfuensis) y pasto tanner (Brachiaria arrecta); MN - Cyperus spp.; MA escobilla (Sida acuta) y las leguminosas Mimosa pudica y M. pigra; y LN - especies de los generos Desmodium, Rhynchosia y Centrosema.

Los componentes botánicos considerados en la extrusa esofágica fueron: Arachis pintoi, leguminosas nativas, gramíneas y otras especies. Se tomó una submuestra de $400 \mathrm{~g}$ de extrusa fresca, que se extendió uniformemente en una bandeja, que se examinó. La composición botánica de la extrusa se calculó a partir de 400 puntos observados bajo el microscopio estereoscópico a lo largo de la bandeja. Esta técnica es una modificación de la empleada por Harker et al(10).

La conducta de alimentación en pastoreo, se midió por observación directa de las actividades de apacentamiento, ya fuese visual, auditiva, o ambas cosas a la vez(2). Estas mediciones se efectuaron un día sí y dos días no, por lo cual en el ciclo de pastoreo de 21 días se realizaron siete mediciones. En el primer ciclo de pastoreo se midió la conducta de alimentación en las ocho vacas que pastaron la pastura asociada, y en el segundo periodo, en las otras ocho que estuvieron en gramas nativas solas. La actividad de las vacas intactas se clasificó en: apacentamiento o pastoreo (TP, $\mathrm{min} / 24 \mathrm{~h}$ ), cuando se observó visualmente al animal con su cabeza baja, cerca del suelo, prehendiendo - a punto de prehender una porción de la pastura; rumia (TR, min/24 h), cuando la vaca estaba rumiando tanto de pie como echada; y otras actividades (TO, min/24 h), si el animal no pastaba ni rumiaba y estaba parado, echado o caminando. Estas variables se registraron en cada animal a intervalos de 10 min por $24 \mathrm{~h}$ continuas, iniciando a las $1500 \mathrm{~h}$. El tiempo total por actividad fue el producto del número de registros por $10 \mathrm{~min}$, suponiendo que cada registro representó la actividad en los $10 \mathrm{~min}$
The botanical components considered in esophageal extrusa were: Arachis pintoi, native legumes, grasses and other species. A subsample of $400 \mathrm{~g}$ of fresh extrusa was spread evenly on a tray and was examined. The botanical composition of the extrusa was calculated from 400 points observed under the stereomicroscope along the tray. This technique is a modification of that used by Harker et a/(10).

The grazing feeding behavior was measured by direct observation of grazing activities, either visual, auditory, or both at once(2). These measurements were made every $3 \mathrm{~d}$, so, a total of seven measurements were performed during the $21-d$ grazing cycle. In the first grazing cycle feeding behavior of the eight cows grazing on the experimental NPA associated pasture was measured, and in the second period, the grazing behavior of the other eight cows grazing on the NP control was measured. The activity of intact cows were classified as: Grazing (GT, $\min / 24 \mathrm{~h}$ ) when visually observed that the animal had its head down near the ground, or about to grasp a portion of the pasture; rumination ( $R T$, min/24 h), when the cow was ruminating both standing or lying down; and other activities (OT, min/24 h), if the animal was not grazing or ruminating and was standing, lying down or walking. These variables were recorded for each animal at intervals of $10 \mathrm{~min}$ for 24 continuous hours, starting at $1500 \mathrm{~h}$. The total time for activity was the product of the number of records per $10 \mathrm{~min}$, assuming that each record represented the activity of the previous $10 \mathrm{~min}$. An interval time of $10 \mathrm{sec}$ was used to confirm the activity recorded.

The biting rate (BR, bites/min) and bite size (BS, g OM/bite) were estimated using both the esophageal fistulated cows, which were allowed to graze for 30 to $40 \mathrm{~min}$ in the morning and in the afternoon, during which bites were counted in the effective grazing time, usually $30 \mathrm{~min}$. The BR was equal to the number of bites registered, divided by the effective grazing time. The bite was defined as the characteristic sound produced when the forage is separated 
posteriores. Se emplearon 10 seg para confirmar la actividad registrada.

La tasa de bocados (TB, bocados/min) y el tamaño de bocado (TM, g MO/bocado) se estimaron usando las dos vacas fistuladas al esófago, a las que se permitió pastar por 30 a 40 min en la mañana y en la tarde, tiempo durante el cual se contaron los bocados en el tiempo efectivo de apacentamiento, usualmente 30 min. La TB fue igual al número de bocados registrados entre el tiempo efectivo de apacentamiento. El bocado se definió como el sonido característico producido cuando el pasto es separado de la pastura por la vaca, lo cual es fácilmente audible(11). El TM se calculó dividiendo el peso de la materia orgánica (MO) de extrusa esofágica colectada, entre el número total de bocados, ambas variables registradas durante el tiempo efectivo de apacentamiento. En la extrusa esofágica, se determinaron los contenidos de MS, MO y proteína cruda(12). Si bien la información generada a partir de la extrusa no permite valorar con exactitud la calidad de la dieta, sí permite generar valores que indican diferencias entre dietas que permitan explicar los resultados productivos.

Para medir el consumo de materia seca se utilizó sesquióxido de cromo $\left(\mathrm{Cr}_{2} \mathrm{O}_{3}\right)$ como marcador externo para estimar la producción diaria de excremento. Las vacas intactas se dosificaron diariamente por 21 días con exactamente $4 \mathrm{~g} /$ día del marcador. Se consideró que los primeros 14 días eran necesarios para lograr el estado de flujo continuo y uniforme del marcador a lo largo del tracto gastrointestinal; las muestras fecales se colectaron individualmente directamente del recto de cada animal, en los últimos siete días. Se formó una muestra de excremento compuesta a partir de alícuotas diarias, y el contenido de $\mathrm{Cr}$ se determinó por espectroscopia de absorción atómica(13). La producción de excremento se obtuvo con la fórmula: [( $\mathrm{g}$ de $\mathrm{Cr}$ dosificados)*(Tasa de recuperación)] / [Cr] en excremento; se supuso una tasa de recuperación del $82.5 \%$, con base en la información presentada por Danes et a(14). from the pasture by the grazing cow, which is easily audible(11). The BS (g OM/bite) was calculated by dividing the weight of organic matter (OM) of esophageal extrusa collected by the total number of bites, both variables registered during the actual duration of grazing variables. In esophageal extrusa, the contents of DM, OM and crude protein were determined(12). While the information generated from the extrusa did not allow for accurate assessment of the quality of the diet, it nevertheless can generate values that indicate differences between diets that allow explaining the productive results.

To measure the dry matter intake chromium sesquioxide $\left(\mathrm{Cr}_{2} \mathrm{O}_{3}\right)$ was used as an external marker to estimate the daily production of feces. Intact cows were dosed daily for $21 \mathrm{~d}$ to exactly $4 \mathrm{~g} / \mathrm{d}$ of the marker. We considered the first $14 \mathrm{~d}$ were necessary to achieve the steady state flux of the marker along the gastrointestinal tract; feces samples were individually collected directly from the rectum of each animal, in the last seven days. A composite feces sample was made from daily aliquots and its $\mathrm{Cr}$ content determined by atomic absorption spectroscopy(13). Production of feces was obtained by the formula: [(dosed $\mathrm{g}$ of $\mathrm{Cr}$ ) * (recovery rate)] / $[\mathrm{Cr}]$ in feces; a recovery rate of $82.5 \%$ was assumed, based on the information published by Danes et $\mathrm{a}(14)$. The DM digestibility of ingested grass (extrusa) was estimated using the in situ method for $48 \mathrm{~h}$ of ruminal incubation(15) of extrusa esophageal samples, which were introduced as dried and ground (Wiley Mill \# 4 sieve $1 \mathrm{~mm}$ ) in triplicate into the rumen. The rumen fistulated animals used, -consumed forage under freely grazing conditions in a pasture of 6.6 ha, mainly formed by Tanner grass (Brachiaria arrecta), star (Cynodon nlemfuensis) and native grass (Paspalum spp, Axonopus spp) and received from $5 \mathrm{~d}$ before to finish all runs, $2 \mathrm{~kg}$ of concentrate ( $16 \% \mathrm{CP}, 88 \% \mathrm{DM})$ per animal per day, in order to ensure a uniform microbial population in terms of number and activity; commercial bags employed were built of white monofilament polyester fabric, with pore size 
La digestibilidad de la MS del pasto ingerido (extrusa) se estimó con el método in situ a tiempo de $48 \mathrm{~h}$ de incubación ruminal(15) de muestras de extrusa esofágica, que se introdujeron ya secas y molidas (Molino Wiley \#4, criba de $1 \mathrm{~mm}$ ) por triplicado al rumen; esos animales además del pasto que consumieron libremente en un potrero de 6.6 ha, formado principalmente por los pastos Tanner (Brachiaria arrecta), estrella (Cynodon nlemfuensis) y gramas nativas (Paspalum spp, Axonopus spp) recibieron desde cinco días antes, hasta terminar todas las corridas, $2 \mathrm{~kg}$ de concentrado de engorda (16\% de PC, $88 \%$ de MS) por animal por día, con el fin de asegurar una población microbiana uniforme en número y actividad; las bolsas comerciales empleadas fueron construidas con tela de monofilamento de poliéster color blanco, con tamaño de poro de $53 \pm 10$ micras y son libres de nitrógeno, con tamaño de $10 \mathrm{~cm} \times 20 \mathrm{~cm}$. El consumo de MO (CMO, kg/vaca/día) se calculó como sigue(13): Producción de heces (g MO/vaca/día) / 1 - digestibilidad de la MO.

La producción de leche vendible (PLV, kg/día) se registró diariamente durante los dos ciclos de pastoreo de 21 días que duró el experimento (42 días en total); 15 de las 16 vacas estaban lactando y de éstas, seis estaban criando su becerro, dos en PN y cuatro en PNA. Cada semana se pesaron los becerros antes y después de mamar para obtener por diferencia, el consumo diario de leche por el becerro (CLB, $\mathrm{kg} / \mathrm{día}$ ). La producción de leche total (PLT, kg/ vaca/día) fue la suma de PLV + CLB, y en caso of $53 \pm 10$ microns and free of nitrogen; their size was $10 \mathrm{~cm} \times 20 \mathrm{~cm}$. Intake of OM (OMI, $\mathrm{kg} / \mathrm{cow} / \mathrm{d}$ ) was calculated as follows(13): Production of feces (g OM /cow/d)/ 1 digestibility of $\mathrm{OM}$.

Production of salable milk (SMY, $\mathrm{kg} / \mathrm{d}$ ) was recorded daily during the two grazing cycles of $21 \mathrm{~d}$ of the experiment ( $42 \mathrm{~d}$ total); 15 of the 16 cows were lactating and of these, six were raising their calves, two in NP and four in NPA. Each week the calves were weighed before and after nursing to determine by difference, the daily consumption of milk by the calf $(\mathrm{CMI}, \mathrm{kg} /$ d). The total milk production (TMY, $\mathrm{kg} / \mathrm{cow} / \mathrm{d}$ ) was the sum of SMY + CMI, and if the cow did not have a calf, the SMY was equal to the TMY.

The response variables measured in on pastures and animals had as replicates the paddock and animals, respectively. Analyses of variance were performed using the PROC GLM procedure of SAS(16). In the case of analysis of variance of milk production, covariates used were the number of days of lactation from start the experiment and calving number, as well as the measurement period. In all cases, the level of significance used was $P<0.05$.

In both measurement periods, the minimum and maximum temperatures did not differ greatly from historical averages. However, in period 1 it rained only a quarter of the historical average, while in period 2 it rained $23 \mathrm{~mm}$ more than the historical average (Table 1).

Cuadro 1. Promedios históricos de precipitación y temperaturas mínimas y máximas, así como las ocurridas durante el experimento

Table 1. Historical averages of rainfall (Prec, $\mathrm{mm}$ ) and temperature minimum ( $\mathrm{T} \mathrm{min}$ ) and maximum ( $\mathrm{T}$ max) as well as those that occurred during the experiment

\begin{tabular}{lccccccc}
\hline & \multicolumn{3}{c}{ Historical (1980-1999) } & & \multicolumn{3}{c}{ Experiment (2000) } \\
\cline { 2 - 3 } \cline { 7 - 8 } Experimental period & $\operatorname{Prec}(\mathrm{mm})$ & $\mathrm{T} \min \left({ }^{\circ} \mathrm{C}\right)$ & $\mathrm{T} \max \left({ }^{\circ} \mathrm{C}\right)$ & & $\operatorname{Prec}(\mathrm{mm})$ & $\mathrm{T} \min \left({ }^{\circ} \mathrm{C}\right)$ & $\mathrm{T} \max \left({ }^{\circ} \mathrm{C}\right)$ \\
\hline Period 1 (Jun 25 to Jul 15) & 120 & 22.6 & 31.6 & & 32 & 21.4 & 33.4 \\
Period 2 (Jul 25 to Aug 14) & 119 & 22.5 & 31.3 & & 142 & 20.9 & 33.3 \\
\hline
\end{tabular}


de que la vaca no tuviese becerro, la PLV fue igual a la PLT.

Las variables de respuesta medidas en la pastura y en los animales tuvieron como repeticiones al potrero y a los animales, respectivamente. Los análisis de varianza se realizaron con el procedimiento PROC GLM de SAS(16). En el caso del análisis de varianza de la producción de leche, se emplearon como covariables el número de días en lactancia al iniciar las vacas el experimento y su número de parto, así como el periodo de medición. En todos los casos, el nivel de significancia estadística empleado fue de $P<0.05$.

En ambos periodos de medición las temperaturas mínimas y máximas no difirieron grandemente de las medias históricas. Sin embargo, en el periodo 1 llovió una cuarta parte de la media histórica, en tanto que en el periodo 2 Ilovieron $23 \mathrm{~mm}$ más que la media histórica

La pastura asociada presentó significativamente $27 \%$ más MSP antes del pastoreo que el testigo.

Cuadro 2. Materia seca presente antes de pastar y composición botánica de pasturas de gramas nativas solas 0 asociadas con Arachis pintoi

Table 2. Standing dry matter present before grazing and botanical composition of native grass pastures (NP) alone or associated with Arachis pintoi (NPA)

\begin{tabular}{lcr}
\hline Variable & $\begin{array}{c}\text { Native } \\
\text { grasses (PN) }\end{array}$ & $\begin{array}{c}\text { PN/Arachis } \\
\text { pintoi }\end{array}$ \\
\hline $\begin{array}{l}\text { Standing DM present } \\
\text { before grazing, kg/ha }\end{array}$ & $3314 \pm 212 \mathrm{a}$ & $4225 \pm 212 \mathrm{~b}$ \\
$\begin{array}{l}\text { Botanical composition, \% } \\
\text { Arachis pintoi CIAT 17434 }\end{array}$ & $\ldots \ldots$ & $28.3 \pm 3.9 \mathrm{~b}$ \\
native grasses & $58.7 \pm 2.1 \mathrm{a}$ & $45.0 \pm 2.1 \mathrm{~b}$ \\
introduced grasses & $10.2 \pm 1.5 \mathrm{a}$ & $4.3 \pm 1.5 \mathrm{~b}$ \\
Savannah grass & $11.7 \pm 1.2 \mathrm{a}$ & $5.2 \pm 1.2 \mathrm{~b}$ \\
(Sporobolus poiretii) & $2.8 \pm 0.7 \mathrm{a}$ & $4.1 \pm 0.7 \mathrm{a}$ \\
Sour grass & $10.1 \pm 0.7 \mathrm{a}$ & $6.9 \pm 0.7 \mathrm{~b}$ \\
(Paspalum virgatum) & $6.6 \pm 0.9 \mathrm{a}$ & $6.2 \pm 0.9 \mathrm{a}$ \\
Broadleaf weeds & & \\
Native legumes &
\end{tabular}

ab Means with the same letter are statistically insignificant $(P>0.05)$.
The Arachis pintoi associated with native grasses (NPA) provided $27 \%$ more SDM before grazing than the NP control pasture. The contribution of $A$. pintoi to the botanical composition was approximately $28 \%$. The contributions of native grasses, introduced grasses and savanna grass were significantly higher in the control compared to the association. The control also had significantly 1.5 times more broadleaf weed than the associated pasture (NPA). The contribution of sourgrass and native legumes were statistically similar in both types of grass pastures (Table 2).

The percentage of $A$. pintoi in the esophageal extrusa was 1.5 times higher than that present in the pasture from it was collected (Tables 2 and 3), while the amount of grass in PN was significantly higher than that of NPA. The content of native legumes and other species in

Cuadro 3. Medias de tratamientos para variables del comportamiento ingestivo, extrusa esofágica y consumo

Table 3. Treatment means for feeding behavior variables, esophageal extrusa and intake

\begin{tabular}{lrr}
\hline Variable & $\begin{array}{c}\text { Native } \\
\text { grasses (PN) }\end{array}$ & $\begin{array}{c}\text { PN/Arachis } \\
\text { pintoi }\end{array}$ \\
\hline Esophageal extrusa: & & \\
Arachis pintoi, \% & $0.0 \pm 0.0 \mathrm{a}$ & $43.6 \pm 2.3 \mathrm{~b}$ \\
Grasses, \% & $98.2 \pm 2.4 \mathrm{a}$ & $56.0 \pm 1.8 \mathrm{~b}$ \\
Native legumes, \% & $1.7 \pm 0.2 \mathrm{a}$ & $0.0 \pm 0.0 \mathrm{~b}$ \\
Other species, \% & $0.1 \pm 0.5 \mathrm{a}$ & $0.4 \pm 0.1 \mathrm{a}$ \\
Crude protein, \% of DM & $10.6 \pm 0.5 \mathrm{a}$ & $15.1 \pm 0.4 \mathrm{~b}$ \\
In situ digestibility of OM & $64.1 \pm 2.4 \mathrm{a}$ & $67.6 \pm 1.7 \mathrm{~b}$ \\
(\% of OM) & & \\
Ingestive behavior: & $380 \pm 11.0 \mathrm{a}$ & $367 \pm 11.0 \mathrm{a}$ \\
Grazing time, min/d & $379 \pm 8.0 \mathrm{a}$ & $291 \pm 8.0 \mathrm{~b}$ \\
Rumination time, min/d & & \\
Time from other activities, & $677 \pm 14.0 \mathrm{a}$ & $776 \pm 14.0 \mathrm{~b}$ \\
min/d & $35.4 \pm 1.0 \mathrm{a}$ & $22.0 \pm 1.1 \mathrm{~b}$ \\
Biting rate, bites/min & $0.68 \pm 0.06 \mathrm{a}$ & $0.96 \pm 0.04 \mathrm{~b}$ \\
Bite size, g OM/bite & & \\
Organic matter intake: & & \\
Cr-situ digestibility & & \\
(kg OM/100 kg BW) & $0.68 \pm 0.06 \mathrm{a}$ & $2.09 \pm 0.11 \mathrm{a}$ \\
Feeding behavior & & \\
(kg OM/100 kg BW) & $2.02 \pm 0.12 \mathrm{a}$ & $1.54 \pm 0.12 \mathrm{~b}$ \\
\hline
\end{tabular}

ab Means with the same letter in a row are statistically different $(P<0.05)$. 
La contribución de Arachis pintoi a la composición botánica fue aproximadamente $28 \%$. Las contribuciones de gramíneas nativas, gramíneas introducidas y el pasto sabana fueron significativamente mayores en el testigo con respecto a la asociación. Asimismo, el testigo tuvo significativamente 1.5 veces más arvenses de hoja ancha que el tratamiento PNA. La contribución de pasto amargo y leguminosas nativas fue estadísticamente igual en ambos tratamientos (Cuadro 2).

El porcentaje de $A$. pintoi en la extrusa esofágica fue 1.5 veces más que el de la pastura (Cuadros $2,3)$, en tanto que la cantidad de gramíneas en PN fue significativamente mayor que aquélla de PNA. El contenido de leguminosas nativas y otras especies en la extrusa esofágica, por ser muy reducido, no fue factor determinante en el consumo de MS o la calidad de la dieta.

La proteína cruda y la digestibilidad in situ de la MO de la extrusa esofágica fueron significativamente mayores en PNA que en PN (Cuadro 3). Tanto el efecto lineal como el cuadrático del porcentaje de $A$. pintoi en la extrusa fueron significativos sobre digestibilidad in situ de la MO y la PC y (Figura 1), siendo las ecuaciones respectivas:

DISMO $=29.40+1.14 *$ PCTAP $-0.0129 *$ PCTAP2, $\mathrm{R}^{2}=0.25, \mathrm{n}=28 ;(P<0.05)$

$\mathrm{PC}=3.35+0.53 * \mathrm{PCTAP}-0.0056 * \mathrm{PCTAP}^{2}, \mathrm{R}^{2}=$ $0.39, \mathrm{n}=28 ; \quad(P<0.05)$

El tiempo de apacentamiento fue estadísticamente similar en ambos tratamientos, en tanto que el tiempo de rumia fue significativamente menor en PNA con respecto a PN. La diferencia en tiempo dedicado a otras actividades fue significativa a favor de PNA. La tasa de bocados de PN fue significativamente mayor a la de PNA, ocurriendo lo opuesto con el tamaño de bocado. El consumo de MO por el método del doble marcador fue similar entre tratamientos (Cuadro 3). Por el contrario, el consumo de MO calculado a partir del comportamiento ingestivo resultó en valores the esophageal extrusa, was very small, therefore it was not the determining factor in DM intake or diet quality.

Crude protein and in situ OM digestibility of esophageal extrusa were significantly higher in NPA than in NP (Table 3). Both the linear and the quadratic effect of the percentage of $A$. pintoi in extrusa were significant for in situ digestibility of $O M$ and PC (Figure 1), the following being their respective equations:

DISMO $=29.40+1.14 *$ PCTAP $0.0129 *$ PCTAP2 $, R^{2}=0.25, \mathrm{n}=28 ;(P<0.05)$

$P C=3.35+0.53 * P C T A P-0.0056 * P C T A P 2$, $\mathrm{R}^{2}=0.39, \mathrm{n}=28 ;(P<0.05)$

Grazing time was statistically similar in both treatments, while rumination time was significantly lower in NPA with respect to NP. The difference in time spent on other activities was significant in favor of NPA. The biting rate of NP was significantly higher than that of NPA, while the opposite occurred with bite size. OM

Figura 1. Relación entre el contenido de Arachis pintoi con la proteína cruda (CP) y la digestibilidad in situ de materia orgánica (ISOMD)

Figure 1. Relationship between Arachis pintoi content with crude protein (CP) and in situ organic matter digestibility (ISOMD)

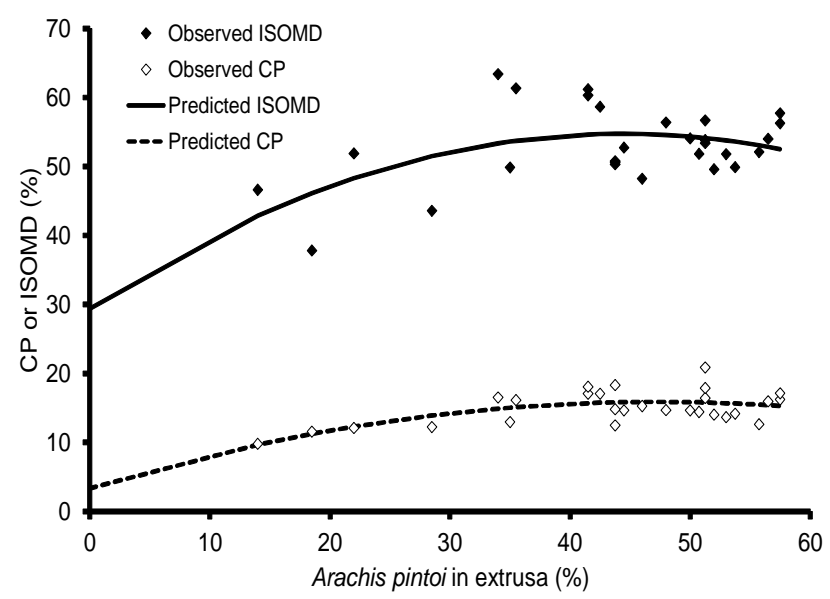

OBS $=$ observed; $\mathrm{PRED}=$ predicted 
menores, presentando el tratamiento testigo un consumo significativamente mayor al de la asociación.

La producción de leche vendible y el consumo de leche del becerro fueron estadísticamente iguales entre tratamientos. Sin embargo, la producción total de leche por vaca de la pastura asociada superó significativamente la del testigo (Figura 2).

En un experimento de pastoreo, la MSP tiene poco valor por sí misma. Es más racional expresar la MSP en términos de disponibilidad: unidades de forraje ofrecido por unidades de peso vivo animal, ya que así puede relacionarse tanto con el consumo como con el desempeño productivo por animal(17).

En pastos tropicales, la disponibilidad para alcanzar una producción por animal máxima es variable, desde 5 hasta $35 \mathrm{~kg} \mathrm{MS} / 100 \mathrm{~kg} \mathrm{PV}$; este amplio rango se debe a diferencias entre experimentos con respecto a tipo de pastura, calidad nutricia y manejo, lo cual dificulta aplicar los resultados de un experimento a situaciones particulares.

El rumiante en pastoreo ingiere hojas y muy poco tallo, por lo que sería razonable expresar la disponibilidad como MS-verde(18) o mejor, en términos de MS-verde de hoja. En el presente caso, el contenido de material senescente fue prácticamente nulo, de tal forma, la disponibilidad, aún no expresada como tal, fue principalmente MS-verde. Asimismo, durante el estudio la disponibilidad promedio fue de 10.9 y $12.2 \mathrm{~kg}$ MS/100 kg PV en las pasturas testigo y asociada, respectivamente, lo que cae dentro del amplio rango citado. Además, la disponibilidad promedio fue de 5.0 y 5.8 veces el consumo de materia seca estimado mediante la técnica de $\mathrm{Cr}_{2} \mathrm{O}_{3}$ digestibilidad in situ (Cuadro 3).

Las tasas de utilización de la MSP del presente experimento fueron 14.0 y $11.5 \%$ para PN y PNA, respectivamente. Previamente, Monsalve et al(19) estimaron tasas de utilización de 11.4 y $13.6 \%$ para los mismos tratamientos, valores intake by dual marker method was similar for both pastures (Table 3). In contrast, intake of OM calculated from feeding behavior resulted in lower values, showing that the NP control treatment had significantly increased intake as compared to the experimental pasture association

The production of salable milk and calf milk consumption were statistically equal between treatments. However, the total production of milk per cow in the pasture association significantly exceeded that of the control (Figure 2).

In a grazing experiment, the SDM has little value by itself. It is more rational to express the SDM in terms of availability: fodder units offered per units of animal live weight, as this may be related to both the OM intake and the production performance per animal(17).

In tropical pastures availability to achieve maximum production per animal is variable from

Figura 2. Medias de producción individual de leche en pasturas de grama nativa solas (PN) 0 asociadas con Arachis pintoi (PNA)

Figure 2. Means of milk production per cow of native grass pastures (PN) alone or associated with Arachis pintoi (PNA)

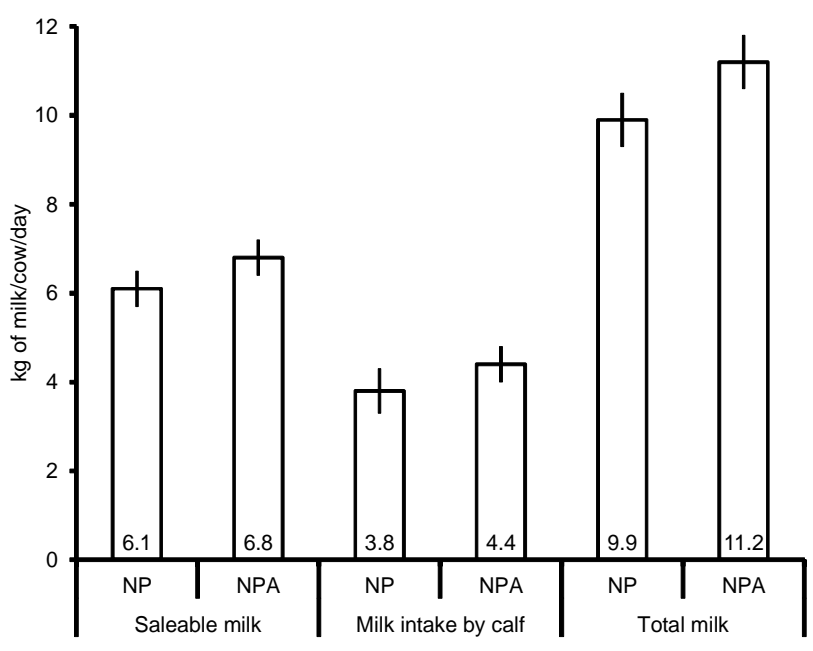

Vertical lines on bars are standard errors. 
que concuerdan en lo general con la literatura, que indica bajos niveles de utilización para pasturas tropicales, de entre 10 y $40 \%$ (19).

La MSP puede influir por si misma sobre el consumo y la producción de leche. Cowan y O'Grady(20) mostraron que la producción de leche por vaca era constante cuando la $M S P>2,500 \mathrm{~kg} / \mathrm{ha}$, pero que por debajo de los $2,000 \mathrm{~kg}$ tanto el consumo y el tiempo de pastoreo se reducían. Por lo tanto, en el presente experimento las vacas en ambos tratamientos no estuvieron expuestas a niveles deficitarios de MSP que limitaran el consumo voluntario (Cuadro 2).

La calidad de la MSP fue suficientemente alta como para no presentar límites al consumo de forraje. Los valores de PC estuvieron en todos los casos por arriba del rango crítico de 6 a $8 \%$ por abajo del cual una deficiencia de $\mathrm{N}$ para los microbios ruminales es más probable y podría reducir el consumo. Asimismo, los valores de digestibilidad de la MO estuvieron en la parte alta del rango para pasturas tropicales, con 0 sin leguminosas, citado por Minson(3). Esto concuerda con otros resultados(21) para el valor nutritivo de muestras obtenidas imitando manualmente el pastoreo de los componentes gramínea y leguminosa de dos asociaciones de gramíneas con $A$. pintoi, pastadas a dos cargas animales.

En las vacas fistuladas al esófago, la tasa de bocados fue mucho menor, y el tamaño de bocado mucho mayor que en los animales intactos. Las grandes diferencias podrían deberse a las distintas formas de generar tal información, pues las 8 vacas intactas no se dietaron y por ende, sus patrones de apacentamiento fueron los usuales. Por otro lado, las dos vacas fistuladas del esófago, se dietaron por varias horas antes del muestreo, lo cual interrumpió sus patrones normales de conducta de alimentación al pastar.

Hess et a/(22) compararon los contenidos de leguminosa de novillos fistulados al esófago e
5 to $35 \mathrm{~kg} \mathrm{MS} / 100 \mathrm{~kg} \mathrm{PV}$; this wide range is due to differences among experiments with respect to type of pasture, nutritional quality and management, which makes it difficult to apply the results of an experiment to particular situations.

The grazing ruminant eats leaves and very little stem, so it would be reasonable to express availability as green-DM(18) or better yet, in terms of leaf green-DM. In this case, content of senescent material was practically zero, hence, the availability, although not explicitly expressed as such was nevertheless primarily green-DM. Also, during the study the average availability was 10.9 and $12.2 \mathrm{~kg}$ DM/100 kg PV in NP and NPA pastures respectively, which falls within the wide range quoted above. In addition, the average availability was 5.0 and 5.8 times that of the dry matter intake estimated by the technique of in situ digestibility- $\mathrm{Cr}_{2} \mathrm{O}_{3}$ (Table 3).

The utilization rates of MSP of the present experiment were 14.0 and $11.5 \%$ for NP and NPA, respectively. Previously, Monsalve et al(19) estimated utilization rates of 11.4 and $13.6 \%$ for the same treatments. These values generally agree with the literature, indicating low levels of use for tropical pastures, between 10 and $40 \%(19)$.

The SDM can itself influence intake and milk production. Cowan and O'Grady(20) showed that milk production per cow was constant when MSP> 2,500 kg/ha, but below 2,000 kg/ha, both consumption and grazing time were reduced. Therefore, in the present experiment, the cows in both treatments were not exposed to deficient levels of SDM as to limit the voluntary intake (Table 2).

The quality of the SDM was high enough so as to present limits in forage intake. The $\mathrm{CP}$ values were in all cases above the critical range of 6 to $8 \%$ which is below the level that $\mathrm{N}$ deficiency would affect rumen microbes and likely cause reduced intake. Also, the digestibility values of 
intactos, cuando pastaron una asociación $B$. humidicolalA. pintoi y encontraron que los animales fistulados seleccionaron a favor de la leguminosa en las épocas de lluvias y sequía, en tanto que los intactos seleccionaron en contra de la leguminosa en las lluvias, pero a favor en la sequía. Los novillos fistulados se dietaron durante la noche, antes de colectar la extrusa, en tanto que los intactos no, sugiriendo la posibilidad de la dieta nocturna alterara la selectividad del novillo. En el presente estudio las vacas seleccionaron a favor de la leguminosa, lo cual concuerda con lo encontrado por Ibrahim(21) cuyos novillos se comportaron de manera similar.

Las diferencias entre tratamientos en PC y DISMO fueron muy evidentes y pueden atribuirse a la contribución significativa de $A$. pintoi a la composición botánica de la extrusa (Cuadro 2, Figura 1). La relación observada entre el contenido de $A$. pintoi y el contenido de PC de la extrusa es parecida a la encontrada por Ibrahim(21), que colectó extrusa de novillos fistulados al esófago que pastaron una asociación de $B$. brizantha/ $A$. pintoi en Costa Rica. Lo anterior sugiere que dicha leguminosa tiene la capacidad de mantener su contenido de $\mathrm{N}$ en diferentes ecosistemas y condiciones de manejo, la cual es una característica deseable si se desea mejorar pasturas de gramas nativas - pasturas degradadas de gramíneas introducidas.

Existen pocos informes de la literatura sobre los niveles de consumo de MS o MO de pasturas asociadas. En la misma estación experimental, Fernández et a/(23), emplearon el método agronómico de la diferencia para estimar el consumo de MS y no encontraron diferencias estadísticas entre pasturas de gramas nativas solas, con un rango de $2.53 \pm 0.65$ a $4.51 \pm$ $0.69 \mathrm{~kg} \mathrm{MS} / 100 \mathrm{~kg} \mathrm{PV}$, y asociadas con $A$. pintoi, cuyo rango fue de $2.52 \pm 1.05$ a 3.34 $\pm 0.82 \mathrm{~kg} \mathrm{MS} / 100 \mathrm{~kg}$ PV. Por su parte, AlonsoDíaz et al(24) emplearon la misma técnica en una pastura de gramas nativas, por un periodo de tres años, y encontraron un consumo
OM were in the upper range for tropical pastures, with or without legumes, as indicated by Minson(3). This is consistent with other results(21) for the nutritional value of samples obtained by hand-plucking the grass and legume components of two grasses associated with $A$. pintoi, grazed at two different stocking rates.

In the esophageal fistulated cows, biting rate was much lower, and bite size much greater than in the intact animals. These large differences could be due to differences in how such information was generated; the 8 intact cows were not fasted and thus their grazing patterns were usual. On the other hand, the two esophageal fistulated cows were fasted for several hours before sampling, which interrupted their normal feeding behavior patterns to graze.

Hess et al(22) compared the legume content of the esophageal fistulated steers and intact when grazing on an association of $\mathrm{B}$. humidicola/A. pintoi and found that fistulated animals selected for the legume in the rainy and dry seasons, while the intact selected against the legume in the rainy, but not in the dry. The fistulated steers were dieted overnight before collecting the extrusa, while the intact were not, suggesting that nocturnal fast time alters diet selectivity of steers. In the present study cows selected for the legume, which agrees with the findings of Ibrahim(21) where steers behaved similarly.

Differences between treatments in $\mathrm{CP}$ and ISDMO were evident and can be attributed to the significant contribution of $A$. pintoi to the botanical composition of extrusa (Table 2, Figure 1). The observed relationship between the content of $A$. pintoi and PC content in extrusa is similar to that found by Ibrahim(21), who collected extrusa from esophageal fistulated steers that grazed an association of $B$. brizanthal A. pintoi in Costa Rica. This suggests that this legume has the ability to keep its content of $\mathrm{N}$ under different ecosystems and pasture management conditions, which is a desirable trait if you want to improve native grass pastures or degraded pastures of introduced grasses. 
promedio de $2.3 \pm 1.5 \mathrm{~kg} \mathrm{MS} / 100 \mathrm{~kg}$ PV. En el presente estudio, el consumo de forraje de ambos tratamientos estuvo dentro de lo esperado para pastos tropicales(25).

A. pintoi no fue capaz de estimular el consumo de forraje, sustituyendo sólo a la gramínea. El mayor contenido de PC y mayor digestibilidad de la dieta sugeridos por los análisis efectuados en la extrusa de la asociación, hubiesen sugerido mayor consumo, lo cual no ocurrió. La transferencia neta de proteína del alimento a los intestinos del rumiante en pastoreo con frecuencia no es completa y hay pérdidas ruminales al exceder el valor de $210 \mathrm{~g}$ de $\mathrm{PC} /$ $\mathrm{kg}$ de $\mathrm{MO}$ digestible(26). En el presente estudio, PN y PNA presentaron 165 y $223 \mathrm{~g} \mathrm{PC/kg}$ de MO digestible, respectivamente, lo que sugiere que en la asociación ocurrieron pérdidas netas en transferencia de PC, por deficiencia de energía en el rumen. Se ha afirmado(26) que si las leguminosas logran incrementar el consumo en $30 \%$, podrían proveer suficiente proteína al intestino como para aumentar la producción de leche en $2.6 \mathrm{~kg} / \mathrm{vaca} /$ día. Esto no ocurrió en el presente experimento, donde el consumo fue menor en las pasturas asociadas.

La inhabilidad de $A$. pintoi para mejorar el consumo de MO, sugiere que se deben probar alternativas nutricionales que permitan usar eficientemente la proteína extra que consumen las vacas. Agregar grano de maíz a la dieta no sólo aumentaría directamente el consumo de MO, sino también proveería más energía digestible para evitar el desperdicio de PC en el rumen(26). Tal alternativa funcionaría a nivel individual, más debe ser valorada económicamente antes de probarla experimentalmente.

La estimación del consumo de MO a partir de la conducta de alimentación produjo valores menores de consumo que la técnica de $\mathrm{Cr}$ digestibilidad in situ, siendo el consumo en PN significativamente mayor que en PNA por $31 \%$ (Cuadro 2). No obstante, los valores de consumo por este método están dentro del amplio rango esperado para pasturas tropicales(3). El uso
There are few reports in the literature on consumption levels OM or DM in associated pastures. In the same experimental station, Fernández et al(23) used the agronomic difference method to estimate DM intake and found no statistical differences between native grass pastures alone, with a range from $2.53 \pm$ 0.65 to $4.51 \pm 0.69 \mathrm{~kg} \mathrm{DM} / 100 \mathrm{~kg} P V$, and associated with $A$. pintoi, which ranged from $2.52 \pm 1.05$ to $3.34 \pm 0.82 \mathrm{~kg} \mathrm{DM} / 100 \mathrm{~kg} \mathrm{PV}$. In addition, others (24) used the same technique in a pasture of native grasses for a period of three years, and found an average consumption of $2.3 \pm 1.5 \mathrm{~kg} \mathrm{DM} / 100 \mathrm{~kg} \mathrm{PV}$. In the present study, forage intake of both treatments was within expected ranges for tropical grasses(25).

A. pintoi was not able to stimulate forage intake, but only replaced the grass. The higher $\mathrm{CP}$ content and higher digestibility of the diet suggested by the analysis in the extrusa of the association, had suggested increased intake, which did not happen. The net transfer of feed protein to the intestines of ruminant grazing is often not complete and there are ruminal losses when the value of $210 \mathrm{~g}$ of $\mathrm{CP} / \mathrm{kg}$ digestible $\mathrm{OM}(26)$ is exceeded. In the present study, NP and NPA showed 165 and $223 \mathrm{~g} \mathrm{CP} / \mathrm{kg}$ digestible OM, respectively, suggesting that the association occurred in net losses in PC transfer, because of an energy deficiency in the rumen. Poppi and MC Lennan(26) stated that if legumes are able to increase consumption by $30 \%$, could provide enough protein to the intestine to increase milk production by $2.6 \mathrm{~kg} / \mathrm{cow} / \mathrm{d}$. This did not occur in the present experiment, where consumption was lower in the associated pastures.

The inability of $A$. pintoi to improve OM intake, suggests that nutritional alternatives need to be tested to determine how cows can use efficiently the extra protein consumed. Adding corn grain to the diet not only directly increases consumption of $\mathrm{OM}$, but also provides more digestible energy to avoid waste of $P C$ in the rumen (26). Such alternative can work individually, but it should be evaluated economically before testing experimentally. 
combinado de vacas intactas y fistuladas para estimar tiempo de pastoreo y tamaño de bocado, respectivamente, provocó sesgos en la estimación de consumo. De ahí que las estimaciones de consumo voluntario empleando animales intactos (sin cirugías) y marcadores son la mejor alternativa para estudiar el consumo de forraje en pastoreo.

En la pastura asociada, las vacas encontraron más MS presente, lo que les permitió obtener un bocado más grande que en la pastura testigo de gramas nativas, reduciendo su tasa de bocados en el primer caso, y aumentándola en el segundo (Cuadro 2), lo cual llevó a que la tasa de alimentación de PN (24.1 g MO/min) fuera ligeramente superior a la de PNA $(21.1 \mathrm{~g}$ $\mathrm{MO} / \mathrm{min}$ ); esto, en combinación con un tiempo de pastoreo sólo 13 min mayor, llevó a una diferencia en consumo de $1.4 \mathrm{~kg}$ de MO/vaca a favor del testigo.

Los rumiantes dietados por varias horas presentan un mayor impulso para pastar, evidenciado por una mayor tasa de consumo, que aquellos animales que no han sido dietados(27). El dietado también altera los patrones alternos de apacentamiento y rumia y lleva a mayores tiempos de pastoreo, pero no a diferencias en tamaño de bocado(28). Sin embargo, Chacón y Stobbs(29) afirmaron que el efecto del dietado nocturno era pequeño en comparación con las características de la pastura, pero indicaron que el tiempo de dietado debe ser el mínimo necesario para obtener una tasa de alimentación satisfactoria. Además, el protocolo de muestreo debe interrumpir el pastoreo sólo por el tiempo necesario para colocar bolsas colectoras y obtener la extrusa esofágica. Investigadores brasileños, han obtenido buenos resultados no dietando las vacas fistuladas al esófago $(30,31)$.

El menor tiempo de rumia presentado por la asociación, hubiese sugerido una mayor rapidez de degradación física del forraje pastado y por consiguiente un mayor consumo, producto de una tasa de paso del alimento más acelerada,
The estimated OM intake from feeding behavior resulted in lower values that the technique of in situ $\mathrm{Cr}$-digestibility, intake in NP being significantly higher than in NPA by $31 \%$ (Table $2)$. However, the consumption values for this method are within the expected range for large tropical pastures(3). The combined use of intact and fistulated cows to estimate grazing time and bite size, respectively, led to bias in the estimation of intake. Hence voluntary intake estimates using intact animals (no surgery) and markers are the best alternative to study forage intake on pasture.

In the experimental NPA pasture, cows found more DM present, allowing them to get a bigger bite than in the control which consisted of native grass pasture, thus reducing biting rate in the first case, and increasing it in the latter (Table $2)$, which led to a feeding rate of NP $(24.1 \mathrm{~g}$ $\mathrm{OM} / \mathrm{min}$ ) being slightly higher than that of NPA (21.1 g OM/min); this, in combination with a grazing time only $13 \mathrm{~min}$ higher, led to a difference in intake of $1.4 \mathrm{~kg} \mathrm{OM} /$ cow in favor of the control.

Ruminants prevented from grazing for several hours had greater impetus to graze, evidenced by a higher rate of intake than those animals that have not been limited(27). Fasting also alters patterns of grazing and rumination and leads to longer grazing times, but not to differences in bite size(28). However, Chacon and Stobbs(29) stated that the effect of night fasting was small compared with the characteristics of the pasture, but indicated that fasting time should be the minimum necessary to obtain a satisfactory rate of feeding. In addition, the sampling protocol should stop grazing only for the time necessary to place collection bags and get esophageal extrusa. Brazilian researchers have obtained good results not dieting esophageal fistulated cows $(30,31)$.

The lower rumination time presented by the experimental NPA pasture, suggests a faster physical degradation of grazed forage and therefore higher forage intake, as a product of 
lo cual no sucedió. Entonces, en pasturas asociadas de gramíneas y leguminosas herbáceas como la presente es necesario estudiar qué factores afectan la rapidez con que pasa el forraje ingerido a través del tracto gastrointestinal del animal y que están limitando el consumo.

El tiempo que los animales experimentales estuvieron fuera de las pasturas fue en promedio $265 \mathrm{~min} /$ día; el tránsito de ida y vuelta a la sala de ordeño fue de $30 \mathrm{~min}$, alrededor de 10 min en el ordeño y 60 min para amamantar el becerro. Esto dejó mucho tiempo "muerto" tanto antes que las vacas fueran ordeñadas y después del amamantamiento; este periodo es mucho mayor al periodo de ordeño de 120 a 130 min informado por Cowan(32). Este factor redujo sin duda el tiempo de pastoreo de las vacas del presente estudio.

Un experimento de pastoreo de corta duración como el presente, no es representativo del desempeño productivo animal de un ciclo completo de producción(33). No obstante, permite relacionar el desempeño a corto plazo con características de la pastura que permitan identificar el tipo de opciones de manejo que optimicen la adquisición de forraje por el rumiante(25).

Las diferencias entre tratamientos en leche vendible y leche consumida por el becerro no fueron significativas, pero sí lo fueron en leche total. El mayor consumo de nutrientes en la pastura asociada producto de un mayor valor nutritivo, fue el factor responsable de tal diferencia(34).

El valor nutritivo de la extrusa esofágica de las vacas que pastaron la asociación fue superior a la de las gramas nativas sin leguminosa. Sin embargo, no existieron diferencias entre tratamientos en consumo de $\mathrm{MO}$, por lo cual el consumo de PC y MO digestible fue mayor en la asociación, y en consecuencia, en una producción total de leche mayor.

Este tipo de estudios debe considerar la variabilidad climática dentro y entre años. Por a higher rate of passage of food, which did not happen. Hence, in pastures with grasses and associated herbaceous legumes such as this, it is necessary to study what factors affect how quickly the ingested forage passes through the gastrointestinal tract of the animal and what is limiting its consumption.

The time that the experimental animals were out of in the pasture averaged $265 \mathrm{~min} / \mathrm{d}$. The traffic to and from the milking parlor was 30 min, about 10 min for milking and 60 min for feeding the calf. This left much "dead" time both before the cows were milked and after calf suckling. This period is much greater than the milking period of 120 to 130 min reported by Cowan(32) for their cows. This factor undoubtedly reduced grazing time of cows in this study.

A grazing experiment of short duration such as this is not representative of the animal production performance in terms of a complete production cycle(33). However, it permits the study of the relationships between short term performance and pasture characteristics that would allow the identification of pasture management options that optimize forage acquisition by the grazing ruminant(25).

Differences between treatments in salable milk and milk consumed by the calf were not significant, but they were in terms of total milk. The increased consumption of nutrients in the experimental association pasture resulting from a high nutritional quality, was the factor responsible for such difference(34).

The nutritional value of the esophageal extrusa of cows that grazed the experimental associated pasture was higher than that of the native grasses without legumes. However, there were no differences between treatments in terms of $\mathrm{OM}$ intake, hence consumption of $\mathrm{CP}$ and digestible OM was greater in the experimental association, and consequently in a total production of more milk. 
lo mismo, debe realizarse en épocas climáticas representativas (lluvias, nortes, sequía) y repetirse por al menos dos años. Esto permitirá corroborar si introducir la leguminosa a la incrementar la producción de leche y becerros en los sistemas de doble propósito del trópico mexicano. pastura nativa es una alternativa viable para

Studies like the one herein presented, should consider climate variability within and between years. Therefore, they should be performed in representative climatic seasons (Rainy, Windy, Dry) and repeated for at least two years. This will confirm whether introducing the legume into a native pasture is a viable alternative option for increasing the production of milk and calves in dual-purpose systems in the Mexican tropics.

\section{ACKNOWLEDGEMENTS}

del CONACYT por apoyar al proyecto "Mejoramiento de un pastizal nativo con la leguminosa Arachis pintoi CIAT 17434" del cual la presente investigación formó parte. A los árbitros porque sus valiosas sugerencias ayudaron a mejorar significativamente la presente nota.

\section{LITERATURA CITADA}

1. Wade MH, Carvalho PCF. Defoliation patterns and herbage intake on pastures. In: Lemaire $\mathrm{G}$, et al, editors. Grassland ecophysiology and grazing ecology. 1st ed. Wallingsford, UK: CABI Publishing; 2000:233-248.

2. Penning PD, Rutter SM. Ingestive behaviour. In: Leaver JD, editor. Herbage intake handbook. 2nd ed. Hurley, UK: The British Grassland Society;2004:151-175.

3. Minson DJ. Forage in Ruminant Nutrition. 1st edition. New York, USA: Academic Press; 1990.

4. Carulla JE, Lascano CE, Ward, JK. Selectivity of resident and oesophageal fistulated steers grazing Arachis pintoi and Brachiaria dictyoneura in the Llanos of Colombia. Trop Grasslds 1991;25:317-324.

5. Hernández M, Argel PJ, I brahim MA, Mannetje L. 't. Pasture production, diet selection and liveweight gains of cattle grazing Brachiaria brizantha with or without Arachis pintoi at two stocking rates in the Atlantic Zone of Costa Rica. Trop Grasslds 1995;29:134-141.

6. Hess HD, Kreuzer M, Nösberger J, Wenk C, Lascano CE. (2002). Effect of sward attributes on legume selection by oesophageal-fistulated and non-fistulated steers grazing tropical grass-legume pasture. Trop Grasslds 2002;36:227238.

7. Castillo GE, Braulio Valles MB, Mannetje L 't, Aluja SA. Efecto de introducir Arachis pintoi sobre variables del suelo de pasturas de grama nativa del trópico húmedo mexicano Téc Pecu Méx 2005;43:287-295.
We like to thank the Sistema de Investigación del Golfo de México of CONACyT for supporting the project "Improvement of a native pasture with the legume Arachis pintoi CIAT 17434" which was part of this investigation. The referees for their valuable suggestions helped to significantly improve this paper.

\section{End of english version}

8. Haydock KP, Shaw NH. The comparative yield method for estimating dry matter yield of pasture. Aust J Exp Agric Anim Husb 1975; 15:663-667.

9. Mannetje L. 't, Haydock KP. The dry-weight-rank method for the botanical analysis of pasture. J Br Grassld Soc 1963; 18:268-275.

10. Harker KW, Torell DT, Van Dyne GM. Botanical examination of forage from esophageal fistulas in cattle. J Anim Sci 1964;23:465-469.

11. Chilibroste $P$, Tamminga S, Boer H. Effects of length of grazing session, rumen fill and starvation time before grazing on dry-matter intake, ingestive behaviour and dry-matter rumen pool sizes of grazing lactating dairy cows. Grass For Sci 1997; 52:249-257.

12. Association of Official Agricultural Chemists International. Official methods of analysis (of AOAC international). Gaithersburg, MD: AOAC International; 1997.

13. Penning PD. Animal based techniques for estimating herbage intake. In: Penning PD, editor. Herbage intake handbook. $2^{\text {nd }}$ edition. Hurley, UK: The British Grassland Society; 2004:53-93.

14. Danes MAC, Chagas LJ, Pedroso AM, Santos FAP. Effect of protein supplementation on milk production and metabolism of dairy cows grazing tropical grass. J Dairy Sci 2013;96:407419. 
15. Ørskov ER, Mc Donald I. The estimation of protein degradability in the rumen from incubation measurements weighted according to rate of passage. J Agric Sci Camb 1979; $92: 499-503$.

16. Statistical Analysis System. SAS/STAT ${ }^{\circledR}$ Software: Changes and Enhancements. Release 8.1. Cary, NC: SAS Institute Inc.; 2000.

17. Mott GO. Grazing pressure and the measurement of pasture production. Proc VIII International Grassland Congress. 1960:606-611.

18. Mannetje L 't. Relations between pasture attributes and liveweight gains on a sub-tropical pasture. In: I glovikov VG, Movsissiants AP, editors. Proc XII International Grassland Congress. Moscow, Soviet Union. 1974, Vol. III: 299-304.

19. Monsalve LRA, Sosa MC, Castillo GE, Jarillo RJ, Aluja SA, Mannetje $L$ 't. Efecto de asociar gramas nativas con Arachis pintoi ClAT 17434 sobre el comportamiento ingestivo de vacas de doble propósito [resumen]. Reunión Nacional de Investigación Pecuaria. 2000:89.

20. Cowan RT, O'Grady P. Effect of presentation yield of a tropical grass-legume pasture on grazing time and milk yield of Friesian cows. Trop Grasslds 1976;10:213-218.

21. Ibrahim MA. Compatibility, persistence and productivity of grass-legume mixtures for sustainable animal production in the Atlantic Zone of Costa Rica. [doctoral thesis] Wageningen, The Netherlands: Wageningen Agricultural University; 1994.

22. Hess HD, Kreuzer M, Nösberger J, Wenk C., Lascano CE. Effect of sward attributes on legume selection by oesophageal-fistulated and non-fistulated steers grazing tropical grass-legume pasture. Trop Grasslds 2002;36:227238.

23. Fernández TL, Castillo GE, Ocaña ZE, Valles MB, Jarillo RJ. Características de la vegetación en gramas nativas solas 0 asociadas con Arachis pintoi ClAT 17434 en pastoreo rotacional intensivo. Téc Pecu Méx 2006;44:365-378.

24. Alonso DMA, Castillo GE, Basurto $\mathrm{CH}$, Jarillo RJ, Valles MB. Respuesta productiva de una pastura de gramas nativas bajo pastoreo rotacional intensivo en clima cálido húmedo. Avan Inv Agropec 2007;11:35-55.

25. Stobbs TH. Factors limiting the nutritional value of grazed tropical pastures for beef and milk production. Trop Grasslds 1975; 9:141-150.

26. Poppi DP, Mc Lennan SR. Protein and energy utilization by ruminants at pasture. J Anim Sci 1995;73:278-290.

27. Newman JA, Penning PD, Parsons AJ, Harvey A, Orr RJ. Fasting affects intake behaviour and diet preference of grazing sheep. Anim Behav 1994;47:185-193.

28. Greenwood GB, Demment MW. The effect of fasting on short term cattle grazing behaviour. Grass For Sci 1988;43:377-386.

29. Chacón E, Stobbs TH. The effect of fasting prior to sampling and diurnal variation on certain aspects of grazing behaviour in cattle. Appl Anim Ethol 1997;3:163-171.

30. Lima MLP, Berchieli TT, Nogueira JR, Ruggieri AC, Aroeira LJM, Salman AKD, Soares JPG. Estimativa do consumo voluntário do capim Tanzania (Panicum maximum Jacq. cv. Tanzania) por vacas em lactacao sob pastejo rotacionado. Rev Bras Zoot 2001;30:1919-1924.

31. Soares JPG, Aroeira LJ M, Verneque RS, Pereira OG, Martins CE, Valadares FSC, Ferreira WJ. Estimativas do consumo e da taxa de passagem do capim-elefante (Pennisetum purpureum Schum.) sob pastejo de vacas em lactacao. Rev Bras Zoot 2001;30:2183-2191.

32. Cowan RT. Grazing time and pattern of grazing of Friesian cows on a tropical grass-legume pasture. Aust J Exp Agric Anim Husb 1975;15:32-37.

33. Moore JE, Sollenberger LE, Albrecht KA, Beede PT, Brown WF. Effect of regrowth interval upon canopy structure and utilization of Aeschynomene-Limpograss pastures. Proc XVI International Grassland Congress. Nice, France. 1989:10291030.

34. Aroeira LJM, Lopes FCF, Soares JPG, Deresz F, Verneque RS, Arcuri PB, de Matos LL. Daily intake of lactating crossbred cows grazing elephantgrass rotationally. Pesq Agrop Bras 2001;36:911-917. 